Brit. J. industr. Med., 1964, 21, 214.

\title{
TOXICOLOGICAL AND BIOCHEMICAL STUDIES ON SOME TRIALKYLGERMANIUM COMPOUNDS
}

\author{
BY \\ JILL E. CREMER and W. N. ALDRIDGE \\ From the Toxicology Research Unit, Medical Research Council Laboratories, \\ Carshalton, Surrey
}

(RECEIVED FOR PUBLICATION JANUARY 24, 1964)

\begin{abstract}
The toxicity of triethyl- and tri-n-butyl-germanium acetates has been studied after their administration to rats. Both compounds had a low toxicity. Triethylgermanium had less than one-tenth of the toxicity of triethyltin or triethyl-lead and, unlike them, it did not appear to have a predominant action on the central nervous system.

In biochemical studies in vitro, tri-n-butylgermanium was found to be more active than trimethyl-, triethyl- or tri-n-propyl-germanium in inhibiting both glucose oxidation by slices of rat brain cortex and processes involved in oxidative phosphorylation by rat liver mitochondria. All the germanium compounds tested had less than one-hundredth the activity of the corresponding trialkyltin and trialkyl-lead compounds.
\end{abstract}

The toxicity and biochemical actions of a series of trialkyltin and trialkyl-lead compounds have been studied in considerable detail in this laboratory over the past few years. In both groups of compounds the lower members of the series have been shown to be toxic to animals with a predominant action on the central nervous system. Detailed symptomatological descriptions of the action of trialkyltins on rats and rabbits have been given by Barnes and Stoner (1958), Stoner, Barnes, and Duff (1955), and Magee, Stoner, and Barnes (1957), and of trialkylleads by Cremer (1959) and Cremer and Callaway (1961). Biochemical studies have mainly been concerned with the action of trialkyltin and trialkyllead compounds on glucose metabolism by rat brain (Cremer, 1957, 1959, 1961, 1962; Aldridge, Cremer, and Threlfall, 1962) and on processes involved in oxidative phosphorylation by mitochondria isolated from rat liver (Aldridge, 1958; Aldridge et al., 1962).

We now wish to report some similar data for a series of trialkylgermanium compounds. Unlike the trialkyltin and trialkyl-lead compounds, trialkylgermanium compounds have a low toxicity to rats and are relatively inert in the biochemical systems we have studied. Although the results were largely negative, their publication seemed warranted since possible commercial uses of trialkylgermanium compounds are under investigation. They indicate that the toxicological hazards to man from the use of trialkylgermanium would be less than those from the corresponding tin and lead compounds.

\section{Materials and Methods}

Pure samples of the germanium compounds were supplied by Dr. G. M. van der Want of the Institute for Organic Chemistry T.N.O., Utrecht, Holland.

Adult albino rats of $175-230 \mathrm{~g}$. body weight were used.

Administration of Germanium Compounds in Animals. Triethylgermanium acetate was given to rats either intravenously (tail vein) as a solution in ethanol $(0.05 \mathrm{ml}$. per rat) or orally by stomach tube as a solution in arachis oil. Tri-n-butylgermanium acetate was given to rats orally as a solution in arachis oil followed nine days later by an intraperitoneal injection as a solution in dimethylformamide. (Each rat received not more than $0 \cdot 1 \mathrm{ml}$. dimethylformamide.)

Mitochondria.-Mitochondria were isolated from rat liver by the procedure previously described (Aldridge, 1958). Respiration of the mitochondria was measured in the presence and absence of apyrase (Aldridge and Stoner, 1960). Details are given in the footnote to Table 2. The adenosine-triphosphatase (ATP-ase) activity of the mitochondria was measured in the presence and absence of $30 \mu \mathrm{M}$ 2:4-dinitrophenol (DNP), as previously described by Aldridge (1958). 
TABLE 1

TOXICITY OF TRIETHYL- AND TRI-N-BUTYL-GERMANIUM TO MALE RATS

\begin{tabular}{|c|c|c|c|c|c|c|}
\hline Compound & $\begin{array}{l}\text { No. of } \\
\text { Animals }\end{array}$ & $\begin{array}{c}\text { Dose } \\
(\mathrm{mg} . / \mathrm{kg} .)\end{array}$ & Route & Reaction & Death & $\begin{array}{l}\text { Time of Death } \\
\text { after Injection }\end{array}$ \\
\hline Triethylgermanium acetate & $\begin{array}{l}4 \\
4 \\
4 \\
4\end{array}$ & $\begin{array}{l}50 \\
\\
31 \cdot 25 \\
62 \cdot 5 \\
125 \\
250\end{array}$ & $\begin{array}{l}\text { I.V. } \\
\text { Oral } \\
\text { Oral } \\
\text { Oral } \\
\text { Oral }\end{array}$ & $\begin{array}{l}1 \text { rat immediately after the injection had } \\
\text { violent convulsions, collapsed and died. } \\
\text { Surviving rats initially showed rapid breath- } \\
\text { ing and remained in a stretched out position } \\
\text { for } 2 \text { hr. By } 18 \text { hr. recovery was complete } \\
\text { No signs of poisoning } \\
\text { Slight loss of weight during first week, } \\
\text { thereafter regained weight } \\
\text { Loss of weight during first week, thereafter } \\
\text { regained weight } \\
\text { No obvious cause of death. Liver very dark } \\
\text { and lungs haemorrhagic }\end{array}$ & 1 & $\begin{array}{l}1 \text { minute } \\
1-2 \text { hours }\end{array}$ \\
\hline $\begin{array}{l}\text { Tri-n-butylgermanium } \\
\text { acetate }\end{array}$ & $\begin{array}{l}4 \\
4 \\
4 \\
4 \\
4\end{array}$ & $\begin{array}{l}111 \\
\text { after } 9 \\
250 \\
167 \\
250 \\
\text { after } 9 \\
125 \\
375\end{array}$ & $\begin{array}{l}\text { Oral } \\
\text { ays } \\
\text { I.P. } \\
\text { Oral } \\
\text { Oral } \\
\text { ays } \\
\text { I.P. } \\
\text { Oral }\end{array}$ & $\begin{array}{l}\text { Some weight loss after I.P. } \\
\text { injection } \\
\text { No signs of poisoning } \\
\text { Some weight loss after I.P. } \\
\text { injection } \\
\text { No signs of poisoning }\end{array}$ & & \\
\hline
\end{tabular}

Brain Slices.-Rat brain cortex slices were prepared and used as described by Cremer (1957). The details are given in the footnote to Table 4.

\section{Results}

Toxicity to Rats.-Only triethyl- and tri-n-butylgermanium were tested. Summaries of the response of the rats are given in Table 1. After the oral administration of triethylgermanium acetate three out of a group of four rats receiving the highest dose died within two hours. Macroscopical immediate post-mortem examination revealed that severe haemorrhage had occurred throughout the lungs, the liver was a deep purple colour, and the right auricle was distended. The intestine, spleen, and kidneys appeared normal. The surviving rat and those receiving $125 \mathrm{mg}$. $/ \mathrm{kg}$. body weight did not gain weight during the first five days after the oral administration, but thereafter they showed a normal weight gain and no other signs of poisoning were detectable.

From the present results it is not possible to determine the $\mathrm{LD}_{50}$ to rats of triethylgermanium but it is probably between 125 and $250 \mathrm{mg} . / \mathrm{kg}$. body weight. This compound has therefore at least less than one-tenth of the toxicity of triethyltin or triethyl-lead.

Tri-n-butylgermanium acetate was administered orally at four different dose levels to groups of rats each containing four animals. No signs of poisoning were observed. Nine days after the oral dose an intraperitoneal injection of tri-n-butylgermanium acetate was given to animals in two of the four groups as indicated in Table 1 . In both of these groups the animals showed some loss of weight but no other signs of poisoning were observed. Tri-n- butylgermanium acetate has a low toxicity to rats.

Mitochondrial Respiration.-Previous work using liver mitochondria had shown that when pyruvate was added as a substrate (with a small amount of 'sparker' fumarate) the rate of oxygen uptake could be increased three- to four-fold by the addition of potato apyrase (Aldridge, 1957). This additional oxygen uptake must therefore be associated with the phosphorylation of adenine nucleotide. Furthermore, this oxygen uptake induced by apyrase was inhibited by low concentrations of trialkyltin (Aldridge, 1958) and trialkyl-lead compounds (Aldridge et al., 1962).

The effect of a series of trialkylgermaniums on unstimulated and apyrase-stimulated respiration of rat liver mitochondria is shown in Table 2 . Tri-

TABLE 2

EFFECT OF TRIALKYLGERMANIUM COMPOUNDS ON RESPIRATION OF RAT LIVER MITOCHONDRIA

\begin{tabular}{|c|c|c|c|}
\hline \multirow{2}{*}{ Trialkylgermanium } & \multirow{2}{*}{$\underset{\text { Molar }}{\text { Concentration }}$} & \multicolumn{2}{|c|}{ Oxygen Uptake ( $\%$ of control) } \\
\hline & & No Apyrase & With Apyrase \\
\hline $\begin{array}{l}\text { Methyl } \\
\text { Ethyl } \\
\text { n-Propyl } \\
\text { n-Butyl }\end{array}$ & $\begin{array}{l}10^{-3} \\
10^{-4} \\
10^{-5} \\
10^{-3} \\
10^{-4} \\
10^{-4} \\
10^{-5}\end{array}$ & $\begin{array}{r}106 \\
96 \\
105 \\
107 \\
122 \\
25 \\
103\end{array}$ & $\begin{array}{r}93 \\
101 \\
94 \\
61 \\
75 \\
0 \\
86\end{array}$ \\
\hline
\end{tabular}

Each flask contained $3 \mathrm{ml}$. of a solution of $p \mathrm{H} 6.8$ containing adenosine 5-phosphate (1.15 mM), ATP (1.06 mM), KCI (0.1 M), $\mathrm{MgCl}_{2}(14 \mathrm{mM})$, ethylenediaminetetra-acetic acid $(1.0 \mathrm{mM})$, potassium phosphate $(15 \mathrm{mM})$, sucrose $(30 \mathrm{mM})$, pyruvate $(10 \mathrm{mM})$, fumarate phospha) and $0.3 \mathrm{ml}$. of mitochondrial suspension equivalent to $0.15 \mathrm{gm}$. wet weight of original liver. Where indicated, sufficient apyrase $0.15 \mathrm{~g}$. wet weight of original liver. Where indicated, sufficient apyrase
to hydrolyse $800 \mu \mathrm{g}$. atom $\mathrm{P} / \mathrm{hr}$. was added. Trialkylgermanium compounds were added as $0.03 \mathrm{ml}$. samples in dimethylformamide. Incubation was at $37^{\circ} \mathrm{C}$. Oxygen uptake was measured at 5-min. intervals from 10 to $40 \mathrm{~min}$. $\mathrm{QO}_{2}$ values $\left(\mu 1 . \mathrm{O}_{2} / \mathrm{mg}\right.$. protein/hr.) were
33 for the unstimulated control and 100 for the control stimulated with apyrase. 
methyl- was the least and tri-n-butylgermanium the most active, the latter compound showing some inhibition of apyrase-stimulated respiration at a concentration of $10^{-5} \mathrm{M}$. The trialkylgermanium compounds were less active than the trialkyltin or trialkyl-lead compounds, which produced $50 \%$ inhibition of apyrase-stimulated respiration at concentrations of $10^{-6} \mathrm{M}$ or less.

Mitochondrial Adenosine Triphosphatase.-The addition of DNP $(30 \mu \mathrm{M})$ to liver mitochondria brings about an approximately 20 -fold increase in ATP-ase activity. Aldridge (1958) has shown that this increase is not affected by respiratory inhibitors, such as cyanide and phenylarsenious acid, but it is inhibited by low concentrations of trialkyltin and trialkyl-lead compounds. From this and other evidence it has been suggested that trialkyltins and trialkyl-leads inhibit a step in the energy-transferring chain between electron transport and the formation of adenosine triphosphate. The effect of trialkylgermaniums on mitochondrial ATP-ase activity is shown in Table 3. Trimethylgermanium acetate at high concentrations inhibited unstimulated ATPase activity but had no effect on the ATP-ase activity stimulated by DNP. Triethyl-, tri-n-propyland tri-n-butyl-germanium compounds resembled the trialkyltin and trialkyl-lead compounds inasmuch

TABLE 3

EFFECT OF TRIALKYLGERMANIUM COMPOUNDS ON ADENOSINE TRIPHOSPHATASE ACTIVITY OF RAT

\begin{tabular}{c|c|c|c}
\hline \multirow{3}{*}{ Trialkylgermanium } & $\begin{array}{c}\text { Molar } \\
\text { Concentration }\end{array}$ & $\begin{array}{c}\text { Adenosine Triphosphatase } \\
\text { Activity } \\
\text { (\% of control) }\end{array}$ \\
\cline { 3 - 4 } & & No DNP & With DNP \\
\hline Methyl & $10^{-3}$ & 40 & 85 \\
& $10^{-4}$ & 60 & 102 \\
Ethyl & $10^{-5}$ & 87 & 102 \\
& $10^{-6}$ & 100 & 102 \\
& $10^{-3}$ & 514 & 47 \\
& $10^{-4}$ & 230 & 94 \\
n-Propyl & $10^{-5}$ & 100 & 100 \\
& $10^{-6}$ & 100 & 100 \\
& $10^{-3}$ & $1004^{*}$ & $59 *$ \\
& $10^{-4}$ & 302 & 37 \\
& $10^{-5}$ & 126 & 82 \\
& $10^{-8}$ & 100 & 100 \\
& $10^{-3}$ & $490^{*}$ & $70^{*}$ \\
& $10^{-4}$ & $293 *$ & $27^{*}$ \\
& $10^{-5}$ & 127 & 89 \\
& $10^{-5}$ & 100 & 100 \\
\hline
\end{tabular}

*The germanium compound was out of solution, and a clearing of the mitochondria within 1 min. indicated gross swelling.

Each beaker contained $3 \mathrm{ml}$. of a solution of $p \mathrm{H} 6.8$ containing ATP $(3 \mathrm{mM}), \mathrm{KCl}(0 \cdot 1 \mathrm{M}), \mathrm{MgCl}_{2}(14 \mathrm{mM})$, EDTA $(1.0 \mathrm{mM})$, glycylglycine $(16.7 \mathrm{mM})$, and sucrose $(30 \mathrm{mM})$. Where indicated, methylformamide were added. The beakers were shaken at $37^{\circ} \mathrm{C}$. Liberation of inorganic phosphate was determined $10 \mathrm{~min}$. after the addition of mitochondria. Control activity was approx. $0.5 \mu \mathrm{g}$. the addition of mitochondria. Control activity was approx. $0.5 \mu \mathrm{g}$.
atom $\mathrm{P} / \mathrm{mg}$. protein $/ \mathrm{hr}$. and this was stimulated by $2: 4$ dinitrophenol $(30 \mu \mathrm{M})$ to approx. $10 \mu \mathrm{g}$. atom $\mathrm{P} / \mathrm{mg}$. protein/hr. as at the higher concentrations they increased the ATP-ase activity of the mitochondria but inhibited the stimulation of ATP-ase by DNP. These results suggest that these three trialkylgermanium compounds do have an inhibitory effect on oxidative phosphorylation processes but that the concentrations required are at least one hundred times greater than for the corresponding trialkyltin and trialkyllead compounds.

When high concentrations of compounds such as the trialkylgermaniums, which are sparingly water soluble, are used, it is very likely that they will cause structural damage to the mitochondria. It is known that damage to intact mitochondria releases latent ATP-ase activity. Gross swelling of the mitochondria was indeed seen when high concentrations of tri-n-propyl- and tri-n-butyl-germaniums were used (Table 3).

Slices of Rat Brain Cortex.-Previous studies on the respiration of rat tissues have shown that the

\section{TABLE 4}

EFFECT OF TRIALKYLGERMANIUM COMPOUNDS ON THE METABOLISM OF SLICES OF RAT BRAIN CORTEX

\begin{tabular}{|c|c|c|c|c|}
\hline \multirow{2}{*}{ Trialkylgermanium } & \multirow{2}{*}{$\begin{array}{c}\text { Molar } \\
\text { Con- } \\
\text { centration }\end{array}$} & \multicolumn{3}{|c|}{$\%$ of Control } \\
\hline & & $\mathrm{QO}_{\mathbf{3}}{ }^{*}$ & $\begin{array}{l}\text { Lactic } \\
\text { Acid }\end{array}$ & $\begin{array}{c}\text { Pyruvic } \\
\text { Acid }\end{array}$ \\
\hline & $\begin{array}{l}1 \times 10^{-4} \\
3 \times 10^{-5}\end{array}$ & 103 & 二 & $=$ \\
\hline $\begin{array}{l}\text { Ethyl } \\
\text { n-Propyl } \\
\text { n-Butyl }\end{array}$ & $\begin{array}{lll}5 & \times & 10^{-4} \\
1 & \times & 10^{-4} \\
3 & \times & 10^{-5} \\
1 & \times & 10^{-4} \\
3 & \times & 10^{-5} \\
3 & \times & 10^{-4} \\
2 & \times & 10^{-6} \\
5 & \times & 10^{-6} \\
2 & \times & 10^{-6}\end{array}$ & $\begin{array}{r}35 \\
66 \\
110 \\
42 \\
95 \\
42 \\
70 \\
89 \\
100\end{array}$ & $\begin{array}{l}485 \\
565 \\
250 \\
410 \\
115 \\
214 \\
280 \\
100 \\
100\end{array}$ & $\begin{array}{r}39 \\
71 \\
100 \\
40 \\
100 \\
34 \\
55 \\
82\end{array}$ \\
\hline
\end{tabular}

* Oxygen uptake

Each flask contained $3.0 \mathrm{ml}$. of Kreb's Ringer phosphate solution with glucose $0.01 \mathrm{M}$, tissue slice $50-60 \mathrm{mg}$. wet weight, $0.03 \mathrm{ml}$. of trialkylgermanium compound in dimethylformamide as indicated, and $0.2 \mathrm{ml}$. of $20 \%(\mathrm{w} / \mathrm{v}) \mathrm{KOH}$ in the centre-well for absorption of $\mathrm{CO}_{2}$. The gas phase was $100 \%$ O $\mathrm{O}_{2}$. Incubation was at $37^{\circ} \mathrm{C}$. for $\mathrm{CO}_{2}$. The gas phase was $100 \% \mathrm{O}_{2}$. Incubation was at $37^{\circ} \mathrm{C}$. for
75 minutes. $\mathrm{QO}_{2}$ was calculated as $\mu \mathrm{l}$. of $\mathrm{O}_{2} / \mathrm{mg}$. dry weight of tissue/ hour. The control $\mathrm{QO}_{2}$ value was $13 \cdot 5$. The control values for lactic and pyruvic acid were $180 \mu \mathrm{g}$. and $10.0 \mu \mathrm{g}$. respectively, estimated as the amount present in the medium after 75 minutes' incubation.

oxidation of glucose by brain slices is particularly sensitive to low concentrations of trialkyltin and trialkyl-lead compounds (Cremer, 1957; Aldridge et al., 1962). Both groups of compounds inhibited oxygen uptake, lowered the level of pyruvic acid, and increased the level of lactic acid. It can be seen from the results given in Table 4 that tri-ethyl-, n-propyl- and n-butyl-germanium acetates inhibited the oxidation of glucose by slices of brain cortex in the manner described above for the corresponding tin and lead compounds. The main difference was 
that the concentrations of the germanium compounds required for inhibition were at least one hundred times greater.

\section{Conclusion}

The results of experiments reported in this paper show that the action on certain biological systems of the trialkylgermanium compounds was similar to that of the trialkyltin and trialkyl-lead compounds, but effective concentrations were over one hundred times greater. The low activity found in biochemical studies in vitro was reflected in the low toxicity to rats. No biological properties peculiar to the trialkylgermaniums were detected and they do not appear to have a predominant action on the central nervous system.

It is of intrinsic interest that the trialkylgermanium compounds have such a relatively low biological activity compared with their analogues of tin and lead since the three metals are in the same subgroup, IVB, of the Periodic Table. Increasing molecular weight of $\mathrm{Ge}<\mathrm{Sn}<\mathrm{Pb}$ is accompanied by increasing basicity. Trialkyltins and trialkyl-leads form coloured complexes with dithizone (Aldridge and Cremer, 1957; Cremer, 1959) but the trialkylgermaniums do not. Whether or not ionic character is an essential prerequisite for biological activity in this series of trialkyl-metals remains to be determined.

Our thanks are due to the Germanium Research Committee for making available, through the Institute for Organic Chemistry T.N.O., Utrecht, Holland, the compounds investigated. We also wish to thank Mr. B. W. Street and Mr. D. Potter for their valuable technical assistance.

\section{REFERENCES}

Aldridge, W. N. (1957). Biochem. J., 67, 423. (1958). Ibid., 69, 367. , and Cremer, J. E. (1957). Analyst., 82, 37. , and and Threlfall, C. J. (1962). Biochem. Pharmacol., 11, 835. Barnes, and Stoner, H. B. (1960). Biochem. J., 74, 148.

Barnes, J. M., and Stoner, H. B. (1958). Brit. J. industr. Med., 15, 15. Cremer, J. E. (1957). Biochem. J., 67, 87. - (1959). Brit. J. industr. Med., 16, 191.

(1961). Biochem. Pharmacol., 6, 153.

(1962). J. Neurochem., 9, 289.

, and Callaway, S. (1961). Brit. J. industr. Med., 18, 277.

Magee, P. N., Stoner, H. B., and Barnes, J. M. (1957). J. Path. Bact., 73, 107 . Stoner, H. B., Barnes, J. M., and Duff, J. I. (1955). Brit. J. Pharmacol., 